\title{
THE ROLE OF PHENYLETHYLAMINE DURING POSITIVE HUMAN-DOG INTERACTION
}

\author{
J. S. J. ODENDAAL ${ }^{1}$, S. M. C. LEHMANN ${ }^{2}$ \\ ${ }^{1}$ Life Sciences Research Institute, ${ }^{2}$ Center for Human and Animal Molecular Health, Technikon Pretoria, \\ Private Bag X680, Pretoria, 001, South Africa \\ Received March 13, 2000 \\ Accepted July 27, 2000
}

Abstract

Odendaal J. S. J., S. M. C. Lehmann: The Role of Phenylethylamine during Positive Human-Dog Interaction. Acta Vet. Brno 2000, 69:183-188.

\begin{abstract}
Physiological parameters for positive human-companion animal behaviour have been few and limited to changes in humans only. Studies of positive interaction among humans and animals of the same species stated that phenylethylamine could be an additional physiological indicator for such behaviour. The purpose of this study was thus to evaluate this neurotransmitter on an interspecies interaction basis. The method was to use a decrease in blood pressure of between 5$10 \%$ from baseline values as parameter, to measure changes in plasma phenylethylamine during positive interaction between humans $(n=18)$ and dogs $(n=18)$. Results indicated that phenylacetic acid, catabolite of $\beta$-phenylethylamine, increased significantly $(p<0.05)$ in both species after interspecies interaction that lasted between 5-24 minutes. If this physiological reaction is mutual, animals used in animal-facilitated therapy can experience the same benefits from such reactions as humans and this is of importance from an animal welfare point of view. Effects on animal welfare and dog ownership have implications in companion animal veterinary practice, because positive interaction between owner and dog may strengthen the psychological bond between the two species.

Human-animal interaction, neurotransmitter, affiliation, behaviour
\end{abstract}

Intraspecies affiliation behaviour only became a field of study on the neurotransmitter level during the nineties (Carter et al. 1997). In social and psychological human studies, dogs are often described as fulfilling a substitute role for other significant persons (Levinson 1962). The problem is that it is unknown whether the same physiological changes on the neurotransmitter level occur during interspecies affiliation behaviour and whether such changes occur simultaneously in both species.

Positive interaction (attention needs) for human-animal interaction are actually based on fulfilling such a need. It was further indicated that positive interaction between humans and animals could be reciprocal (social symbiosis) and this mutual effect can contribute to the success of the therapy. The term used to describe this basic need of positive interaction is attentionis egens. A Latin term was chosen to avoid confusion with attention-seeking behaviour, which is often associated with negative problem behaviour (Odendaal 1999). Walsh (1991) stated however, that:

"Our needs for nurturance, affiliation, and attachment have never, as far as I am aware been considered anything but rooted in the biology of the species."

Fisher (1992) said that attraction (the beginning of positive interaction) might begin with a small molecule, called phenylethylamine, which has an amphetamine-like effect. It is known as the excitant amine, causing feelings of elation, exhilaration and euphoria. Other neurotransmitters, such as dopamine, may also play a role. Phenylethylamine has positive effects on non-humans too, according to behaviour described in mice and Rhesus monkeys

Address for correspondence:

Prof. Dr. Johannes Odendaal

P. O. Box 12855

Pretoria North

Phone: +27125468962

E-mail: odendaalj@techpta.ac.za 
after they had been injected with phenylethylamine or phenylethylamine-like substances. In most identifiable behaviour traits there seems to be a variation in this experience from one individual to another. A continuum of the need for attention may reveal that some people have no or little need for certain types of attention and some may have unusual ways of attracting attention owing to a craving for attention. Hatfield and Rapson (1993) are, however, of the opinion that neuroscientists still know little about the biological basis of companionate, love and tenderness. Physiological parameters for interspecies interaction were limited to changes in humans and include blood pressure, heart rate, plasma triglycerides and cholesterol and skin conductance tests (Friedmann 1995). The aim of this study was to determine the role of a transmitter that is associated with positive interaction on an interspecies basis.

\section{Materials and Methods}

The method to investigate the problem was to create positive human-dog interaction in a quiet, neutral room and take baseline values of the biochemical before intervention and again after intervention. The intervention consisted of dog loving humans, interacting with well-tempered dogs by talking softly, touching and stroking the dogs. Dogs were chosen as a "prototype" for other companion animals and because they are relatively easy to work with during the experiment. The subjects were healthy humans $(n=18)$, older than 18 years $(19-55), 8$ men and 10 women and healthy dogs $(\mathrm{n}=18)$, older than 2 years $(2-12), 7$ males and 11 females. Participants were divided into two groups: the experimental group $(n=9)$ interacted with their own dogs and the control group $(n=9)$ with unfamiliar dogs. Subjects were allowed to settle down in the experimental environment for 10 minutes. Blood pressure was taken continuously with an automatic blood pressure recorder in both species. Five stable readings were taken as baseline and a drop of 5-10\% in blood pressure at five stable readings was taken as after intervention (Yeates and Odendaal 1998). Such a decrease in blood pressure was used as the indicator as to when to collect blood to detect biochemical changes. Blood was collected with a vacutube containing enzyme inhibitors. The blood was centrifuged and chilled to $4^{\circ} \mathrm{C}$. Plasma analyses were done on a diode array high performance liquid chromatograph system for the catabolite of $\beta$-phenylethylalamine, namely phenylacetic acid (Lehmann and de Beer 1998). All dogs were clinically examined by a veterinarian before used in the experiment. The persons presented a declaration that they did not use medication during the duration of the experiment and that they are healthy. Consent forms were completed by the participants as well as the owners of dogs to give permission that their dogs could be used for the experiment. The protocol was approved by the Ethics Committee of the University of Pretoria and the only physical intervention was blood collection.

\section{Results}

The desirable decrease in blood pressure was obtained 5-24 minutes after interaction began. The following tables indicate the differences between phenylacetic acid plasma levels before and after interaction as well as between the two groups. Statistical analysis of the results was made using Wilcoxon rank sum test (Steyn et al. 1994).

Table 1

Mean arterial blood pressure of humans (MAP in $\mathrm{mm} \mathrm{Hg}$ ) before and after interacting positively with own dogs $(n=9)$ and unfamiliar dogs $(n=9)$

\begin{tabular}{|c|c|c|c|c|c|}
\hline $\begin{array}{l}\text { MAP } \\
\text { Own dogs }\end{array}$ & Before & After & $\begin{array}{l}\text { MAP } \\
\text { Unfamiliar dogs }\end{array}$ & Before & After \\
\hline Mean $\pm S D$ & $92.5 \pm 9.0$ & $84.5 \pm 8.2 *$ & Mean \pm SD & $83.4 \pm 14.7$ & $77.3 \pm 14.2 \mathrm{NS}$ \\
\hline Median & 96.2 & 84.5 & Median & 79.6 & 78.6 \\
\hline
\end{tabular}

$* p<0.01$

The decrease of MAP in humans interacting with unfamiliar dogs had not a $p$-value of $<0.05$, but close to that. It is, however, expected that interaction with unfamiliar dogs will have a slightly less significant difference compared to those humans interacting with their own well-known dogs, because of the strangeness of the object. 
Table 2

Concentrations of phenylacetic acid (PAA) (pg/l) in the plasma of humans before and after interacting positively with own dogs $(n=9)$ and unfamiliar dogs $(n=9)$

\begin{tabular}{|lcc|lcc|}
\hline PAA & & & PAA & & \\
Own dogs & Before & After & Unfamiliar dogs & Before & After \\
\hline Mean \pm SD & $122.8 \pm 2.4$ & $140.7 \pm 7.7^{*}$ & Mean \pm SD & $123.0 \pm 3.6$ & $144.1 \pm 11.7^{*}$ \\
Median & 123.0 & 143.7 & Median & 124.0 & 143.0 \\
\hline
\end{tabular}

$* p<0.001$

${ }^{*} p<0.001$

In both human groups the increase in PAA was significant $(p<0.001)$. This occurred concurrently during the decrease of blood pressure.

Table 3

Mean arterial blood pressure (MAP) $(\mathrm{mm} \mathrm{Hg})$ of dogs before and after interacting positively with owners $(\mathrm{n}=9)$ and unfamiliar dog lovers $(\mathrm{n}=9)$

\begin{tabular}{|c|c|c|c|c|c|}
\hline $\begin{array}{l}\text { MAP } \\
\text { Owners }\end{array}$ & Before & After & $\begin{array}{l}\text { MAP } \\
\text { Unfamiliar people }\end{array}$ & Before & After \\
\hline Mean \pm SD & $86.1 \pm 12.9$ & $84.0 \pm 12.8 \mathrm{NS}$ & Mean \pm SD & $103.5 \pm 19.5$ & $93.1 \pm 16.7 *$ \\
\hline Median & 89.2 & 82.6 & Median & 113.6 & 94.0 \\
\hline
\end{tabular}

$* p<0.01$

The non-significant decrease of MAP in the owners' dogs was probably due to the initial excitement that those dogs experienced with their owners in a novel environment. The unfamiliar group of dogs was used to handling by different people in changing environments. It is thus expected that this group be less excited by the same situation.

Table 4

Concentrations of phenylacetic acid (PAA) (pg/l) in the plasma of dogs before and after interacting positively with owners $(n=9)$ and unfamiliar dog lovers $(n=9)$

\begin{tabular}{|c|c|c|c|c|c|}
\hline $\begin{array}{l}\text { PAA } \\
\text { Owners }\end{array}$ & Before & After & $\begin{array}{l}\text { PAA } \\
\text { Unfamiliar people }\end{array}$ & Before & After \\
\hline Mean \pm SD & $56.3 \pm 7.4$ & $91.0 \pm 7.5^{*}$ & Mean \pm SD & $52.8 \pm 8.5$ & $91.5 \pm 8.0^{*}$ \\
\hline Median & 57.0 & 92.0 & Median & 52.0 & 91.0 \\
\hline
\end{tabular}

$* p<0.001$

$* p<0.001$

Despite the slight difference in MAP both groups of dogs showed a significant increase of PAA during positive interaction with humans.

Table 5

Mean arterial blood pressure (MAP) $(\mathrm{mm} \mathrm{Hg})$ of humans $(\mathrm{n}=18)$ and $\operatorname{dogs}(\mathrm{n}=18)$ interacting positively with each other

\begin{tabular}{|lcc|lcc|}
\hline $\begin{array}{l}\text { MAP } \\
\text { Humans }\end{array}$ & Before & After & MAP & Before & After \\
\hline Mean \pm SD & $87.9 \pm 12.7$ & $80.9 \pm 11.8 *$ & Mean \pm SD & $94.8 \pm 18.4$ & $88.6 \pm 15.2 *$ \\
Median & 87.6 & 84.4 & Median & 91.0 & 87.7 \\
\hline
\end{tabular}

$* p<0.001$

$* p<0.001$

If the human and dog groups were taken as species groups, then both species showed a significant decrease in MAP. 
Table 6

Concentrations of phenylacetic acid (PAA) (pg/l) in the plasma of humans $(n=18)$ and $\operatorname{dogs}(n=18)$ interacting positively with each other

\begin{tabular}{|lcc|lcc|}
\hline $\begin{array}{l}\text { PAA } \\
\text { Humans }\end{array}$ & Before & After & PAA & Before & After \\
\hline Mean \pm SD & $122.9 \pm 2.9$ & $142.4 \pm 9.7^{*}$ & Mean \pm SD & $54.6 \pm 7.9$ & $91.2 \pm 7.5^{*}$ \\
Median & 123.5 & 143.0 & Median & 54.5 & 91.5 \\
\hline
\end{tabular}

$* p<0.001$

$* p<0.001$

As in the case with MAP, both species showed a significant change in PAA, however, in the case of PAA the change was an increase. The tables indicate a possible link between the decrease of MAP and an increase of PAA.

\section{Discussion}

Michael Liebowitz (1983) is one of the pioneers in explaining positive interaction biologically. His book "The Chemistry of Love" popularized the concept that any thought, feeling or action people undertake, occurs only because of some form of biochemical activity in the brain. Adding a biological perspective helped him to become more effective in understanding and working with many individuals experiencing relationship difficulties, because there is a biochemical basis for the normal "ups and downs" in relationships. It was also found that there are many similarities between these relationship highs and lows and other intense feelings. The association of psychological and emotional experiences with biochemical changes and vulnerabilities was something very new. The tendency to separate biology from our important emotional experiences has led to a kind of psychiatry with either psychological, or biochemical, thinking. However, people's ability to deal with separation or positive interaction depends on a complex combination of biological (biochemistry), psychological and social (cultural) factors.

An aspect of the effect of natural biochemical substances is (as in the case of administered drugs) that a gradual increase or decrease of the chemical has a less intense effect than sudden changes known as tolerance - the brain learns to tolerate the drug. Changes in receptors are a possible mechanism for this effect. Chronic exposure to certain psychoactive drugs, or an access of the neurotransmitters they stimulate, seems to lead to a reduction in the numbers of receptors, and this may be the explanation for certain forms of drug (or nondrug) experiences losing their impact. Tolerance appears to develop in many unchanging situations to which we are constantly exposed:

"Tolerance to non-drug stimuli may be an important but largely unrecognized aspect of human experience" (Liebowitz 1983).

Other drug principles include physical dependence, rebound and addiction. However, these effects are complex. Human beings cannot be reduced to simple biological reflexes and reactions, but they should also not be treated as entirely spiritual or psychological creatures without bodies and brains. This also applies to animal biology and emotions. Drugs do not create any new biological reactions, but only alter the rate at which ongoing bodily functions proceed. Therefore, the same biochemical mechanisms that govern drug effects may play a role as well in shaping our biological, and thus emotional, reactions to potent non-drug experiences. In general, there are a limited number of ways of feeling good.

Within 30 to 60 minutes after taking $10 \mathrm{mg}$ of amphetamine per os, increased alertness, decreased fatigue, elevated mood, greater initiative and an enhanced sense of self-confidence follow. Intravenous effects tend to be more rapid and more intense. Prolonged use can be followed by mental depression and fatigue when the drug is stopped, or by paranoia leading to 
psychosis if it is continuously administered over a period of days or repeatedly used in escalating doses over a longer period of time. Most human beings find single doses of an amphetamine to be generally pleasurable. However, certain depressed individuals whose brain chemistry is disrupted in some way do not even become temporarily euphoric in response to amphetamine. Sometimes they actually feel more sad or despondent following administration of the drug. Given similarities between drug-induced and naturally occurring excitement, it would appear that any non-drug experience is the result of tapping into some brain chemical reservoir, causing an outpouring of certain neurotransmitters. Just because the chemical effects are the same, it in no way means that amphetamines are a valid substitute for pursing natural pleasure or excitement. What stimulant drug induction does, is to create a sense of excitement without accomplishing anything - a short-circuit of the natural effect (Liebowitz 1983).

The results in this study support the social-psychological theory on a physiological level that dogs can substitute positive human interaction. It also supports the theory that a decrease in blood pressure could be a reliable indicator of neurochemical changes during positive interaction.

For the first time phenylethylamine was determined as indicator of positive interaction on an interspecies basis. The implications are two-fold: first, although theses results were based on effects among healthy people, it can also be used to evaluate psychological effects of animal-facilitated therapy in terms of measurable physiological parameters; second, if the physiological reaction is mutual, animals used in therapy can experience the same feeling of elation form the amphetamine-like neurotransmitter than humans. The facilitator (dog) experiences thus as much a good feeling as the patient and this is of importance from an animal welfare point of view.

Both the effects of positive human-dog interaction and the welfare aspects of dogs are relevant to companion animal veterinary practice. Veterinarians are also involved in multidisciplinary health, teams who practice animal-facilitated therapy. Understanding of the physiological basis of positive interaction can thus be used to the benefit of the veterinary profession in more than one application.

\section{Úloha fenyletylaminu v průběhu pozitivní interakce člověka a psa}

Fyziologických ukazatelů doprovázejících pozitivní chování člověka a zájmových zviŕat je málo a jejich změny byly studovány pouze u člověka. V této studii byla poprvé prokázána úloha neurotransmitteru $\mathrm{v}$ průběhu pozitivní interakce na mezidruhové bazi. Výsledky ukázaly, že koncentrace $\beta$-fenyletylaminu se signifikantně $(P<0.01)$ zvýšila u obou druhů (lidé $\mathrm{n}=18$, psi $\mathrm{n}=18$ ) po jejich mezidruhové interakci. Dosah těchto výsledků, přestože byly získány na zdravých jedincích, je, že se mohou stát základem zvířaty facilitované psychoterapie, protože měřitelné fyziologické změny lze využít $\mathrm{k}$ hodnocení psychoterapeutických postupů. Kromě toho, je-li tato fyziologická reakce vzájemná, může mít stejně pozitivní vliv na zvířata v terapii používaná jako na člověka. Tato skutečnost je významná i z hlediska welfare zvíraat. Vliv na welfare psů a pozitivní stránky držení psa jsou významné i pro praxi malých zviŕat.

\section{References}

CARTER, C. S., ALTEMUS, M. 1997: Integrative functions of lactation hormones in social behaviour and stress management. In: Carter C. S., Lederhendler I. I., Kirkpatrick B. (Eds.) The Integrative Neurobiology of Affililiation. New York Academy of Sciences Annals 807: 164-17 p.

FISHER, H. E. 1992: Anatomy of Love - a natural history of adultery, monogamy and divorce. Simon \& Schuster Ltd. London, pp. 54-57

FRIEDMANN, E. 1995: The role of pets in enhancing human well-being: physiological effects. In: Robinson I. (Ed.) The Waltham Book of Human-Animal Interaction: benefits and responsibilities of pet ownership. Pergamon. Oxford :pp. 33-53 
HATFIELD, H. E., RAPSON, R. L. 1993: Love, Sex and Intimacy: Their Psychology, Biology and History. Harper Collins College Publishers. New York, 49 p.

LEHMANN, S. M. C., DE BEER, W.H. J. 1998: High-Performance Liquid Chromatographic Analysis with Diode Detection of Bradykinin, Neuropeptide K, and Substance P in Human Plasma. J. Chromatographic Science 36: $306-310$

LEVINSON, B. M. 1962: The dog as co-therapist. Mental Hygiene: 46-59

LIEBOWITZ, M. R. 1983: The Chemistry of Love. Little, Brown \& Co Ltd. Boston: 127 p.

ODENDAAL, J. S. J. 1990: Fundamentele gedragspatrone in die rehabilitasierol van geselskapdiere. Rehabilitation in South Africa 34: (2):145-151

ODENDAAL, J. S. J. 1999: A Physiological basis for animal-facilitated psychotherapy. PhD Thesis, University of Pretoria. Pretoria, $50 \mathrm{p}$

STEYN, A. G. W., SMIT, C. F., DU TOIT, S. H. C., STRASHEIM, C. 1994: Modern Statistics in Practice. J. L. van Schaick, Pretoria, 594 p.

WALSH, A. 1991: The Science of Love: understanding love and its effects on mind and body. Prometheus Books, New York: 16, $188 \mathrm{p}$.

YEATES, S. V., ODENDAAL, J. S. J. 1998: Human-dog interaction: an interspecies evaluation of blood pressure changes as possibilities of stress release. $3^{\text {rd }}$ Congress of the International Society for Pathophysiology, Lathi, Finland, 23 June-3 July 1998, Abstracts, 225 p. 